\title{
EFFECT OF FULVIC AND HUMIC ACIDS ON COPPER AND ZINC HOMEOSTASIS IN RATS
}

\author{
István HulláR ${ }^{1 *}$, András Valentin VUCSKITS ${ }^{2}$, Erzsébet BERTA ${ }^{1}$, \\ Emese ANDRÁSOFSZKY ${ }^{1}$, András BERSÉNYI ${ }^{1}$ and József SZABÓ ${ }^{1}$ \\ ${ }^{1}$ Department of Animal Breeding, Nutrition and Laboratory Animal Science, \\ University of Veterinary Medicine, P. O. Box 2, H-1400 Budapest, \\ Hungary; ${ }^{2}$ Europharmavet Ltd., Budapest, Hungary
}

(Received 18 July 2017; accepted 6 November 2017)

The objective of this study was to investigate the effects of fulvic acid (FA) and humic acid (HA), the two main compounds of humic substances (HSs), on copper $(\mathrm{Cu})$ and zinc $(\mathrm{Zn})$ homeostasis. Seventy-two male Wistar rats were randomly divided into nine experimental groups. The control diet (AIN-93G formula) and the diets supplemented with $0.1 \%, 0.2 \%, 0.4 \%$ and $0.8 \%$ FA or HA were fed for 26 days. $\mathrm{Cu}$ and $\mathrm{Zn}$ concentrations of the large intestinal content (LIC), liver, kidney, femur and hair were determined. FA and HA did not influence significantly the $\mathrm{Cu}$ or $\mathrm{Zn}$ contents of the experimental diets, the rats' feed intake, weight gain and the feed to gain ratio. Both FA and $\mathrm{HA}$ decreased the $\mathrm{Cu}$ concentrations of the LIC significantly and in a dose-related manner; however the absorption-stimulating effect of HA was more pronounced. FA increased the $\mathrm{Cu}$ content of the liver, but neither FA nor HA had a dose-dependent effect on it. FA or HA supplementations had no significant effect on the $\mathrm{Cu}$ concentration of the kidney. At the concentrations used, dietary FA or HA supplementations are not promising growth promoters. FA influences the $\mathrm{Cu}$ homeostasis unlike HA, because FA not only stimulates $\mathrm{Cu}$ absorption, but the extra quantity of absorbed $\mathrm{Cu}$ is retained in the organism. The stimulatory effect of HA on $\mathrm{Zn}$ absorption may not be manifested in $\mathrm{Cu}$ and $\mathrm{Zn}$ homeostasis, because of the tight connection of these microelements to FA and HA, which prevents the transmission of $\mathrm{Zn}$ from the $\mathrm{ZnHA}$ complex to the organs. As regards the effect of FA and $\mathrm{HA}$ on $\mathrm{Cu}$ and $\mathrm{Zn}$ homeostasis, both FA and HA stimulated the absorption of these microelements, but only FA increased the retention of $\mathrm{Cu}$ (in the liver) and $\mathrm{Zn}$ (in the kidney).

Key words: Fulvic acid, humic acid, microelement, metabolism

After the ban of antibiotic growth promoters (AGPs), researchers are looking for suitable replacements. Among several other products, humic substances

*Corresponding author; E-mail: hullar.istvan@univet.hu; Phone: 0036 (1) 478-4122

Open Access. This is an open-access article distributed under the terms of the Creative Commons AttributionNonCommercial 4.0 International License (https://creativecommons.org/licenses/by-nc/4.0/), which permits unrestricted use, distribution, and reproduction in any medium for non-commercial purposes, provided the original author and source are credited, a link to the CC License is provided, and changes - if any - are indicated. 
(HSs) have been tested and found to have some positive effects in broilers (Bailey et al., 1996; Eren et al., 2000; Kocabagli et al., 2002) and turkeys (Parks, 1998). HSs are formed from decayed plant matter with the aid of living bacteria in the soil. Their composition includes humus, humic acid (HA), fulvic acid (FA), ulmic acid and microelements necessary for plant development (Stevenson, 1994; Herzig et al., 2000; Andersen et al., 2005; Herzig et al., 2009). Their most active fractions are HA and FA. HSs are soluble in dilute alkaline solutions but HA can be precipitated in acidic medium. Its molecular weight is between 5000 and 100,000 daltons (Da). FA is soluble under all $\mathrm{pH}$ conditions and has the lowest molecular weight, around $2000 \mathrm{Da}$ (Islam et al., 2005).

An important feature of HSs is that they can combine with metal ions, oxides and clay to form water-soluble or insoluble complexes, and interact with organic compounds (Islam et al., 2005). They can affect the macro- and micromineral metabolism of living organisms.

In spite of the fact that HSs can bind metal cations, and an almost infinite number of humic-metallic complexes can be formed (Boyd et al., 1981; Senesi et al., 1985; König et al., 1986; Kang et al., 1991; Livens, 1991), only few studies have dealt with the specific effects of the main components (FA and HA) of HSs on the intestinal absorption of microelements and their concentrations in different animal organs.

Hence, the objective of this study was to investigate the dose-related effects of FA and HA as the two main HSs separately on the production parameters of rats, as well as on the concentration of $\mathrm{Cu}$ and $\mathrm{Zn}$ in the large intestinal content (which may indirectly reflect the absorption of these microelements), and also on $\mathrm{Cu}$ and $\mathrm{Zn}$ concentrations in the liver, kidney, femur and hair of rats. This study is an organic continuation of our previous work (Szabó et al., 2017) which investigated the effects of FA and HA on iron and manganese homeostasis in rats.

\section{Materials and methods}

Animals

Seventy-two weaned, Wistar CRL:(WI) BR male SPF rats were used in this experiment. Animals were housed in individual cages at $24{ }^{\circ} \mathrm{C}$ ambient temperature. After an adaptation period of 4 days, the animals were randomly divided into nine dietary treatment groups on the basis of their body weight.

Diets

The control diet was prepared according to the AIN-93G formula of the American Institute of Nutrition (Reeves, 1997). The experimental diets were prepared by supplementing the control diet with $0.1 \%, 0.2 \%, 0.4 \%$ or $0.8 \%$ of FA or HA to replace starch. The diets were fed for 26 days. Water and feed were provided ad libitum during the experiment. 
HULLÁR et al

\section{HSs fractionation}

Both FA and HA were extracted from leonardite (Szabó et al., 2017).

\section{Measurements and analysis}

The individual body weight and feed consumption of rats were measured three times a week. On the 26th day of the trial rats were euthanised $(90 \mathrm{mg} / \mathrm{kg}$ BW CP ketamine and $0.5 \mathrm{mg} / \mathrm{kg}$ BW medetomidine) and exsanguinated. Samples of large intestinal content, liver, kidney, femur and hair were collected and stored until assayed for $\mathrm{Cu}$ and $\mathrm{Zn}$ concentration. The $\mathrm{Cu}$ and $\mathrm{Zn}$ contents of the samples were determined by a Carl Zeiss Jena AAS3 atomic absorption spectrometer. As regards the hair samples, identical quantities were collected from each animal and pooled in treatment groups because of the low quantities collectible per animal.

The results are expressed as means $\pm \mathrm{SD}$. Statistical analysis of the data was performed by one-way analysis of variance (ANOVA) with Tukey's post hoc multiple comparison test. Response curves were fitted by linear and quadratic regression procedures using MS Excel 2007 software.

The experimental protocol met the standard criteria of the Scientific Ethics Committee of Animal Experiments of the University of Veterinary Medicine, Budapest, Hungary.

\section{Results and discussion}

\section{Effects of FA and HA on the Cu and Zn concentrations of diets}

Table 1 presents the $\mathrm{Cu}$ and $\mathrm{Zn}$ contents of FA, HA and that of the experimental diets. Because of the negligible $\mathrm{Cu}$ and $\mathrm{Zn}$ concentrations of FA and HA, the supplementation levels applied did not change the $\mathrm{Cu}$ and $\mathrm{Zn}$ contents of the experimental diets significantly (Table 1 and Fig. 1). The relative changes of these minerals in the FA- or HA-supplemented diets were maximum $1.81 \%$. On this basis we may assume that the changes in $\mathrm{Cu}$ or $\mathrm{Zn}$ content of the supplemented diets were minimal, and only the chelating ability of FA and HA can be responsible for the presumed effects of FA or HA on $\mathrm{Cu}$ and $\mathrm{Zn}$ homeostasis of the animals.

\section{Effects of FA and HA on production}

The effects of the FA- or HA-supplemented diets on the feed intake, weight gain and feed to gain ratio of rats are summarised in Table 2 .

FA or HA supplementation had no significant influence on the feed intake, weight gain and feed to gain ratio of the rats. These results are in accordance with the findings of Mevlüt et al. (2004) and Kaya and Tuncer (2009) in broilers, and Schuhmacher and Gropp (2000) in weaning pigs. 


\section{Table 1}

Copper $(\mathrm{Cu})$ and zinc $(\mathrm{Zn})$ concentrations of fulvic acid (FA) and humic acid (HA) in the experimental diets $(\mathrm{mg} / \mathrm{kg})$

\begin{tabular}{ccr}
\hline & $\mathrm{Cu}$ & \multicolumn{1}{c}{$\mathrm{Zn}$} \\
\hline FA & 4.38 & 128.00 \\
HA & 6.91 & 8.10 \\
\hline
\end{tabular}

\begin{tabular}{lccccc}
\hline & \multicolumn{5}{c}{ Diets } \\
\hline FA supplementation (\% of diet) & 0.0 & 0.1 & 0.2 & 0.4 & 0.8 \\
$\mathrm{Cu}$ & 7.50 & 7.50 & 7.51 & 7.52 & 7.54 \\
$\mathrm{Relative}$ change of $\mathrm{Cu}$ content (\%) & 0.00 & 0.05 & 0.12 & 0.24 & 0.47 \\
$\mathrm{Zn}$ & 56.1 & 56.2 & 56.4 & 56.6 & 57.1 \\
Relative change of $\mathrm{Zn}$ content (\%) & 0.00 & 0.23 & 0.46 & 0.90 & 1.81 \\
\hline HA supplementation (\% of diet) & 0.0 & 0.1 & 0.2 & 0.4 & 0.8 \\
Cu & 7.50 & 7.51 & 7.51 & 7.53 & 7.56 \\
Relative change of Cu content (\%) & 0.00 & 0.09 & 0.18 & 0.37 & 0.67 \\
Zn & 56.1 & 56.1 & 56.1 & 56.1 & 56.2 \\
Relative change of $\mathrm{Zn}$ content (\%) & 0.00 & 0.02 & 0.04 & 0.05 & 0.11 \\
\hline
\end{tabular}

Remark: $\mathrm{Cu}$ and $\mathrm{Zn}$ content of the basal diet, FA and HA were measured and, based on these values, $\mathrm{Cu}$ and $\mathrm{Zn}$ levels of the supplemented diets were calculated

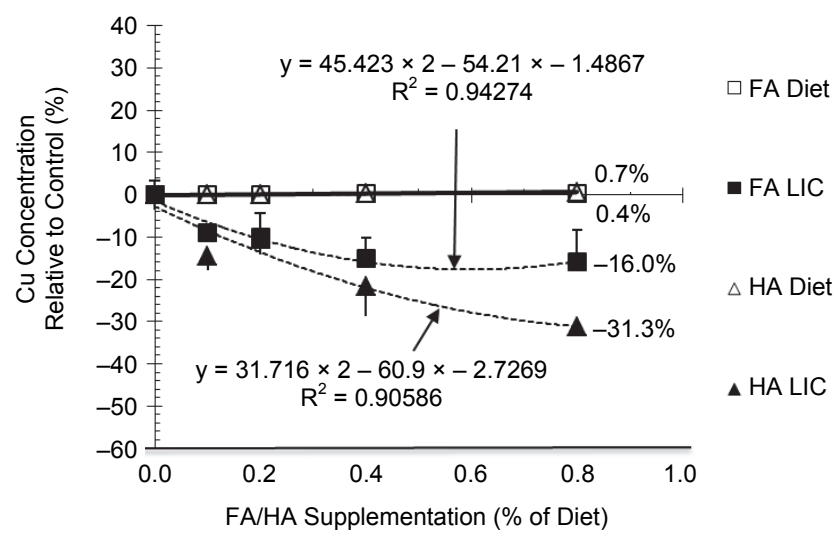

Fig. 1. Effect of fulvic acid (FA) or humic acid (HA) supplementation on the copper $(\mathrm{Cu})$ concentration of diets and that of the large intestinal content (LIC)

In contrast to these results, some published data prove the growthpromoting effect of HSs in broilers (Bailey et al., 1996; Eren et al., 2000; Kocabagli et al., 2002) and turkey toms (Parks, 1998). 
One of the factors responsible for the discrepancies between our data and the results of other researchers regarding the growth-promoting effects of HSs might be the different composition (FA/HA ratio) of humic products on the market (Kocabagli et al., 2002).

Table 2

Effect of fulvic acid (FA) or humic acid (HA) supplementation of diets on feed intake, body weight gain $(\mathrm{BWG})$ and feed to gain ration (mean $\pm \mathrm{SD}, \mathrm{n}=8)$

\begin{tabular}{lccccc}
\hline \multicolumn{5}{c}{ FA } \\
\hline FA (\% of diet) & 0.0 & 0.1 & 0.2 & 0.4 & 0.8 \\
\hline $\begin{array}{l}\text { Feed intake } \\
\text { (g/100 g BW/day) }\end{array}$ & $6.54 \pm 0.19$ & $6.58 \pm 0.40$ & $6.50 \pm 0.35$ & $6.35 \pm 0.52$ & $6.68 \pm 0.43$ \\
$\begin{array}{l}\text { BWG } \\
\text { (g/100 g BW/day) }\end{array}$ & $2.16 \pm 0.19$ & $2.10 \pm 0.18$ & $2.17 \pm 0.12$ & $2.10 \pm 0.12$ & $2.03 \pm 0.11$ \\
Feed/gain (g/g) & $3.02 \pm 0.32$ & $3.14 \pm 0.38$ & $3.00 \pm 0.28$ & $3.04 \pm 0.38$ & $3.30 \pm 0.31$ \\
\hline & 0.0 & 0.1 & 0.2 & 0.4 & 0.8 \\
\hline HA (\% of diet) & \multicolumn{7}{c}{ HA } & & \\
\hline $\begin{array}{l}\text { Feed intake } \\
\text { (g/100 g BW/day) }\end{array}$ & $6.54 \pm 0.19$ & $6.71 \pm 0.34$ & $6.49 \pm 0.41$ & $6.53 \pm 0.24$ & $6.67 \pm 0.31$ \\
$\begin{array}{l}\text { BWG } \\
\text { (g/100 g BW/day) }\end{array}$ & $2.16 \pm 0.19$ & $2.08 \pm 0.14$ & $2.18 \pm 0.16$ & $2.21 \pm 0.11$ & $2.18 \pm 0.18$ \\
Feed/gain (g/g) & $3.02 \pm 0.32$ & $3.23 \pm 0.32$ & $2.98 \pm 0.37$ & $2.95 \pm 0.25$ & $3.06 \pm 0.29$ \\
\hline
\end{tabular}

\section{Effects of FA and HA on the Cu and Zn concentrations of large intestinal} content, liver, kidney, femur and hair

Assuming the effects of FA and HA supplementations on microelement homeostasis, two factors must be taken into consideration, namely the effect of their micro-mineral content and their effects as biologically active substances. We propose that the dose-related relative differences between the $\mathrm{Cu}$ and $\mathrm{Zn}$ concentration changes of the FA- or HA-supplemented diets and the concentrations found in the large intestinal content and the different organs may give direct (microelement concentrations of organs) and indirect (absorption) information about the specific effects of FA and $\mathrm{HA}$ on $\mathrm{Cu}$ and $\mathrm{Zn}$ homeostasis.

For this assumption to be true, there should be no significant differences in the digestibility of organic matter of the experimental diets between the control and treatment groups. As in this study the organic components of the diets were identical and the feed intake, body weight gain and feed to gain ratio did not differ significantly from the control values (Table 2), we can state that this experiment complies with these requirements. 


\section{Copper}

Table 3 and Fig. 1 summarise the $\mathrm{Cu}$ concentration changes in the large intestinal content and in the different organs. Compared to the control values, both FA and HA supplementations significantly decreased the $\mathrm{Cu}$ concentration of the LIC (Table 3 and Fig. 1).

At $0.8 \%$ dietary FA or HA level these decrements were 16.0 and $31.3 \%$, while the increase of $\mathrm{Cu}$ concentrations in the diets was only 0.7 and $0.4 \%$, respectively (Fig. 1).

\section{Table 3}

Effect of fulvic acid (FA) or humic acid (HA) on the copper $(\mathrm{Cu})$ concentration of the large intestinal content (LIC), liver, kidney, femur and hair of rats (mean $\pm \mathrm{SD}, \mathrm{n}=8)$

\begin{tabular}{|c|c|c|c|c|c|}
\hline \multicolumn{6}{|c|}{ FA } \\
\hline FA $(\%)$ & 0.0 & 0.1 & 0.2 & 0.4 & 0.8 \\
\hline \multicolumn{6}{|c|}{$\mathrm{Cu}$ concentration (mg/kg dry matter) } \\
\hline LIC & $143 \pm 4.92^{\mathrm{a}}$ & $130 \pm 2.12^{\mathrm{b}}$ & $128 \pm 8.38^{\mathrm{bc}}$ & $121 \pm 7.09^{\mathrm{cd}}$ & $120 \pm 10.8^{\mathrm{bcd}}$ \\
\hline Liver & $13.5 \pm 0.51^{\mathrm{a}}$ & $14.0 \pm 1.49^{\mathrm{ab}}$ & $15.5 \pm 1.32^{\mathrm{b}}$ & $14.9 \pm 1.81^{\mathrm{ab}}$ & $15.2 \pm 0.83^{b}$ \\
\hline Kidney & $22.3 \pm 2.33$ & $21.8 \pm 5.11$ & $21.5 \pm 1.27$ & $21.8 \pm 1.97$ & $23.3 \pm 2.70$ \\
\hline Femur & $8.95 \pm 0.68$ & $8.58 \pm 0.72$ & $8.73 \pm 0.31$ & $8.98 \pm 0.53$ & $9.25 \pm 0.38$ \\
\hline Hair $^{* *}$ & 12.3 & 12.5 & 12.3 & 12.6 & 12.4 \\
\hline \multicolumn{6}{|c|}{ HA } \\
\hline HA $(\%)$ & 0.0 & 0.1 & 0.2 & 0.4 & 0.8 \\
\hline \multicolumn{6}{|c|}{$\mathrm{Cu}$ concentration (mg/kg dry matter) } \\
\hline LIC & $143 \pm 4.92^{\mathrm{a}}$ & $122 \pm 4.87^{\mathrm{b}^{*}}$ & $128 \pm 5.22^{\mathrm{b}}$ & $112 \pm 9.96^{\mathrm{c}}$ & $98.1 \pm 2.09^{\mathrm{d}^{*}}$ \\
\hline Liver & $13.5 \pm 0.51^{\mathrm{a}}$ & $14.8 \pm 0.96^{\mathrm{b}}$ & $12.4 \pm 0.23^{\mathrm{c}}$ & $14.1 \pm 1.47^{\mathrm{ab}}$ & $13.7 \pm 1.21^{\mathrm{ab}}$ \\
\hline Kidney & $22.3 \pm 2.33$ & $22.6 \pm 1.28$ & $22.5 \pm 0.46$ & $23.4 \pm 0.76$ & $24.5 \pm 0.87$ \\
\hline Femur & $8.95 \pm 0.68$ & $8.88 \pm 0.34$ & $8.98 \pm 0.21$ & $8.80 \pm 0.27$ & $8.77 \pm 0.09$ \\
\hline Hair $^{* *}$ & 12.3 & 12.3 & 12.4 & 12.5 & 12.1 \\
\hline
\end{tabular}

* significant difference between FA and HA groups; ${ }^{* *}$ identical quantities were collected from each animal and pooled in treatment groups

The $\mathrm{Cu}$ concentration changes in the LIC were dose dependent in both the FA- and HA-supplemented rats. The relationships between the dietary and LIC concentration changes of $\mathrm{Cu}$ were polynomial and significant $\left(\mathrm{P}<0.05 ; \mathrm{R}^{2}=\right.$ 0.943 and 0.906 , respectively, Fig. 1). In HA-supplemented rats the $\mathrm{Cu}$ concentrations in the LIC were consistently lower than in the FA-supplemented animals, but the differences between the FA and HA groups of rats were not significant up to the highest investigated doses. 
HULLÁR et al

Compared to the control, $\mathrm{FA}$ increased the $\mathrm{Cu}$ concentration of the liver at all supplementation levels; however, these increases were significant only at the 0.2 and $0.8 \%$ dietary FA levels, suggesting that the Cu-storing capacity of the liver was probably saturated at the $0.2 \%$ dietary FA level.

Because of the very firm bonding strength between $\mathrm{Cu}$ and HA (Rashida, 1974), and of its large molecular weight (Islam et al., 2005; Zraly et al., 2008), we hypothesised that HA would inhibit $\mathrm{Cu}$ absorption. Contrary to this assumption, HA supplementation of the diets significantly stimulated the intestinal absorption of $\mathrm{Cu}$.

The effects of $\mathrm{HA}$ on the $\mathrm{Cu}$ content of the liver were inconsistent: $0.1 \%$ increased, $0.2 \%$ decreased it significantly, while 0.4 and $0.8 \%$ HA supplementation levels had no significant effect on liver $\mathrm{Cu}$ content (Table 3). Neither FA nor $\mathrm{HA}$ had a dose-related effect on the $\mathrm{Cu}$ content of the liver.

FA or HA supplementation had no significant effect on the $\mathrm{Cu}$ concentration of the kidney, femur and hair (Table 3).

The balance between $\mathrm{Cu}$ intake and excretion determines the amount of $\mathrm{Cu}$ in the organism. The intestinal absorption of $\mathrm{Cu}$ is dependent on the highaffinity copper transporter 1 (CTR1) and ATP7A, but other factors such as the divalent metal transporter 1 (DMT1) and the low-affinity copper transporter 2 (CTR2) are also involved in the course of $\mathrm{Cu}$ absorption from the intestinal tract (Peter et al., 2009); however, the entire mechanism is not clearly understood.

Copper is eliminated from the body by the excretion of poorly reabsorbable biliary $\mathrm{Cu}$ (Owen, 1964) and via the urine (Yu and Beynen, 1995).

Summarising these results, we may conclude that both FA and HA dosedependently stimulated $\mathrm{Cu}$ absorption from the intestinal tract and, as a tendency, HA was more efficient than FA. Unlike HA, FA can increase the $\mathrm{Cu}$ content of the liver.

As an indirect conclusion, increased urinary elimination of $\mathrm{Cu}$ absorbed from the intestine of rats fed the HA-supplemented diet can be assumed. The antagonistic effects of FA and HA on $\mathrm{Cu}$ homeostasis can be beneficial in cases of unexplained anaemia in which a $\mathrm{U}$-shaped relationship between serum $\mathrm{Cu}$ levels and unexplained anaemia was reported (Knovich et al., 2008), indicating that both high and low serum $\mathrm{Cu}$ levels are associated with unexplained anaemia in adults.

Zinc

Compared to the control, FA or HA supplementation had no significant effect on the $\mathrm{Zn}$ level of the diet (Table 1).

HA supplementation significantly decreased the $\mathrm{Zn}$ concentration of the LIC $(\mathrm{P}<0.05$; Table 4, Fig. 2), and there was a strong dose-related relationship $\left(\mathrm{R}^{2}=0.985 ; \mathrm{P}<0.05\right)$ between the HA dose and the $\mathrm{Zn}$ concentration change in the LIC of rats. 
Table 4

Effect of fulvic acid (FA) or humic acid (HA) on the zink (Zn) concentration of the large intestinal content (LIC), liver, kidney, femur and hair of rats (mean $\pm \mathrm{SD}, \mathrm{n}=8$ )

\begin{tabular}{|c|c|c|c|c|c|}
\hline \multicolumn{6}{|c|}{ FA } \\
\hline FA $(\%)$ & 0.0 & 0.1 & 0.2 & 0.4 & 0.8 \\
\hline \multicolumn{6}{|c|}{ Zn concentration (mg/kg dry matter) } \\
\hline LIC & $796 \pm 39.2$ & $745 \pm 42.4$ & $753 \pm 16.7$ & $722 \pm 66.0$ & $732 \pm 66.8$ \\
\hline Liver & $105 \pm 11.4$ & $101 \pm 5.28$ & $107 \pm 9.32$ & $103 \pm 13.5$ & $104 \pm 10.2$ \\
\hline Kidney & $96.7 \pm 6.21^{\mathrm{a}}$ & $89.4 \pm 0.93^{b}$ & $91.9 \pm 2.03^{\mathrm{ac}}$ & $90.1 \pm 1.50^{\mathrm{c}}$ & $92.2 \pm 4.72^{\mathrm{c}}$ \\
\hline Femur & $474 \pm 11.3^{\mathrm{a}}$ & $456 \pm 32.0^{\mathrm{ab}}$ & $462 \pm 32.9^{\mathrm{ab}}$ & $469 \pm 19.0^{\mathrm{a}}$ & $444 \pm 14.4$ \\
\hline Hair $^{* *}$ & 289 & 290 & 286 & 297 & 293 \\
\hline \multicolumn{6}{|c|}{ HA } \\
\hline HA $(\%)$ & 0.0 & 0.1 & 0.2 & 0.4 & 0.8 \\
\hline \multicolumn{6}{|c|}{ Zn concentration (mg/kg dry matter) } \\
\hline LIC & $796 \pm 39.2^{\mathrm{a}}$ & $742 \pm 29.3^{b}$ & $736 \pm 34.4^{\mathrm{b}}$ & $667 \pm 41.9^{\mathrm{c}}$ & $597 \pm 91.1^{\mathrm{c}^{*}}$ \\
\hline Liver & $105 \pm 11.4$ & $103 \pm 11.0$ & $97.7 \pm 1.52$ & $106 \pm 9.12$ & $99.6 \pm 4.39$ \\
\hline Kidney & $96.7 \pm 6.21^{\mathrm{a}}$ & $94.4 \pm 5.21^{\mathrm{a}}$ & $93.3 \pm 3.28^{\mathrm{a}}$ & $91.6 \pm 4.60^{\mathrm{a}}$ & $92.1 \pm 4.18^{\mathrm{a}}$ \\
\hline Femur & $474 \pm 11.3^{\mathrm{a}}$ & $455 \pm 7.94^{\mathrm{bc}}$ & $462 \pm 9.81^{\mathrm{abc}}$ & $451 \pm 10.9^{b}$ & $466 \pm 8.52^{\mathrm{ac}}$ \\
\hline Hair $^{* *}$ & 289 & 284 & 290 & 293 & 288 \\
\hline
\end{tabular}

${ }^{*}$ significant difference between FA and HA groups; ${ }^{*}$ identical quantities were collected from each animal and pooled in treatment groups

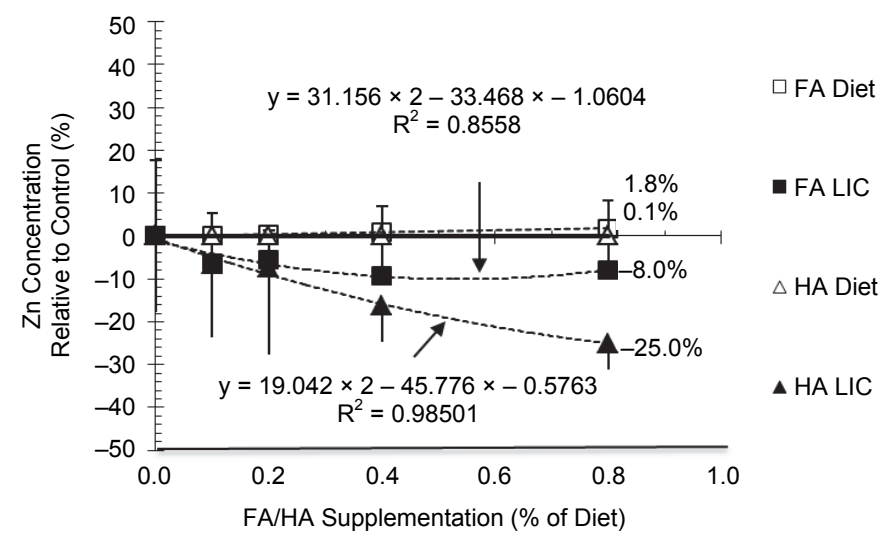

Fig. 2. Effect of fulvic acid (FA) or humic acid (HA) supplementation on the zinc ( $\mathrm{Zn}$ ) concentration of diets and that of the large intestinal content (LIC) 
Neither FA nor HA induced $\mathrm{Zn}$ accumulation in the liver, suggesting that the liver did not receive $\mathrm{Zn}$ from the $\mathrm{ZnFA}$ or ZnHA complexes, probably because of the strong binding between $\mathrm{Zn}$ and FA or HA.

FA supplementation tended to decrease the $\mathrm{Zn}$ content of the kidney, and this decrease was significant at $0.1 \%$ and $0.4 \%$ supplementation levels. There was no significant relationship between the dietary FA dose and kidney $\mathrm{Zn}$ concentrations.

Although FA supplementation did not have a significant influence on $\mathrm{Zn}$ concentration of the LIC compared to the control group, the $\mathrm{Zn}$ levels of the LIC were lower in the FA-supplemented animals than in the control group, and the correlation between the dietary FA dose and the Zn content of the LIC was polynomial and significant $\left(\mathrm{R}^{2}=0.855, \mathrm{P}<0.05\right.$; Fig. 2$)$. HA supplementation tended to decrease the $\mathrm{Zn}$ concentrations compared to the control, but there was no significant difference from the control value even at the highest dose of HA. In contrast to the effect of FA, there was a highly significant quadratic relationship between the dietary HA doses and the $\mathrm{Zn}$ concentration of the kidney tissue $\left(\mathrm{R}^{2}=\right.$ 0.989 ; $\mathrm{P}<0.01$; Fig. 3 ). As an indirect conclusion, we may hypothesise that elimination of the absorbed FA-Zn and HA-Zn complex via the urine may be important in the $\mathrm{Zn}$ homeostasis in rats receiving FA- or HA-supplemented diets.

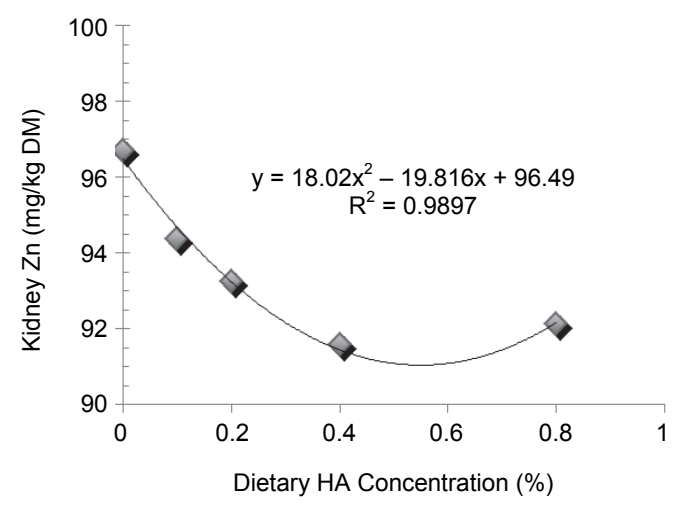

Fig. 3. Dose-dependent relationship between the humic acid (HA) content of the diets and the zinc ( $\mathrm{Zn})$ concentration of the kidney

Based on the pooled data of the FA- or HA-supplemented groups, the $\mathrm{Zn}$ content of the femur decreased significantly; however, this decrease was not always significant in the different treatment groups (Table 4).

Neither FA nor HA supplementation influenced the $\mathrm{Zn}$ content of hair.

Summarising these results, we may conclude that both FA and HA dosedependently stimulated $\mathrm{Zn}$ absorption from the intestinal tract, and that HA tended to be more efficient than FA. 
Data on the $\mathrm{Zn}$ content of the femur suggest the possibility that HA has a sufficiently strong $\mathrm{Zn}$ binding capacity to receive $\mathrm{Zn}$ from the bones and that the ZnFA or ZnHA complexes are probably eliminated via the kidney.

Based upon the $\mathrm{Zn}$ content of the kidneys, we can hypothesise that both FA and HA stimulate the urinary elimination of $\mathrm{Zn}$; however, a dose-effect relationship could be detected only in the HA-supplemented rats.

It is generally accepted that zinc homeostasis is controlled by both its small intestinal uptake through a transcellular saturable carrier-mediated mechanism (Lee et al., 1989) and its excretion via the shedding of epithelial cells and in pancreatic and biliary secretions. In rodents, colonic absorption of zinc also occurs (Hara et al., 2000). The ZIP family of transporters regulates $\mathrm{Zn}$ transport from the intestinal lumen into the cytosol and $\mathrm{ZnT}$ moves $\mathrm{Zn}$ in the opposite direction (Cousins et al., 2006). Both transporter families are expressed along the gastrointestinal tract; however, the mechanism involved in zinc absorption is not fully understood yet.

Finally, we can conclude that, in the concentrations used in this study, dietary FA or HA supplementations are not promising growth promoters. Unlike HA, FA influences $\mathrm{Cu}$ homeostasis, because FA not only stimulates $\mathrm{Cu}$ absorption, but the extra quantity of absorbed $\mathrm{Cu}$ is retained in the organism. The stimulatory effect of $\mathrm{HA}$ on $\mathrm{Zn}$ absorption may not be manifested in $\mathrm{Cu}$ and $\mathrm{Zn}$ homeostasis because of the tight connection of these microelements to FA and HA which prevents the transmission of $\mathrm{Zn}$ from the ZnHA complex to the organs. When evaluating the effect of FA and $\mathrm{HA}$ on $\mathrm{Cu}$ and $\mathrm{Zn}$ homeostasis, we should consider not only their effects on absorption but also on the retention of these elements.

\section{Acknowledgements}

This study was sponsored by the Hungarian Scientific Research Fund (OTKA T049116). The publication of this research was supported by the 12190-4/2017/ FEKUTSTRAT grant of the Hungarian Ministry of Human Capacities.

\section{References}

Andersen, S., Hvingel, B., Kleinschmidt, K., Jørgensen, T. and Laurberg, P. (2005): Changes in iodine excretion in 50-69-y-old denizens of an Arctic society in transition and iodine excretion as a biomarker of the frequency of consumption of traditional Inuit foods. Am. J. Clin. Nutr. 81, 656-663.

Bailey, C. A., White, K. E. and Donke, S. L. (1996): Evaluation of Menefee Humate ${ }^{\mathrm{TM}}$ on the performance of broilers. Poultry Sci. 75 (Suppl. 1), 84. (Abstr.)

Boyd, S. A., Sommers, L. E., Nelson, D. W. and West, D. X. (1981): The mechanism of copper (II) binding by humic acid: an electron spin resonance study of a copper (II)-humic acid complex and some adducts with nitrogen donors. Soil Sci. Soc. Am. J. 45, 745-749. 
Cousins, R. J., Liuzzi, J. P. and Lichten, L. A. (2006): Mammalian zinc transport, trafficking, and signals. J. Biol. Chem. 281, 24085-24089.

Eren, M., Deniz, G., Gezen, S. S. and Türkmen, I. Í. (2000): Effect of broiler feed containing humate on fattening performance, serum mineral concentration and bone ash content [in Turkish]. Ankara Üniv. Vet. Fak. Derg. 47, 255-263.

Hara, H., Konishi, A. and Kassai, T. (2000): Contribution of the cecum and colon to zinc absorption in rats. J. Nutr. 130, 83-89.

Herzig, I., Navratilova, J., Totusek, J., Suchy, P. and Vecerek, V. (2009): The effect of humic acid on zinc accumulation in chicken broiler tissues. Czech J. Anim Sci. 54, 121-127.

Herzig, I., Psarkova, B., Kursa, J. and Suchy, P. (2000): Utilisation of iodine from different sources in pigs. Arch. Tierernähr. 53, 179-189.

Islam, K. M. S., Schuhmacher, A. and Gropp, J. M. (2005): Humic acid substances in animal agriculture. Pakistan J. Nutr. 4, 126-134.

Kang, Y., Yamada, H., Kyuma, K., Hattori, T. and Kigasawa, S. (1991): Selenium in soil humic acid. Soil Sci. Plant Nutr. 37, 241-248.

Kaya, C. A. and Tuncer, S. D. (2009): The effects of humates on fattening performance, carcass quality and some blood parameters of broilers. J. Anim. Vet. Adv. 8, 281-284.

Kocabagli, N., Alp, M., Acar, N. and Kahraman, R. (2002): The effects of dietary humate supplementation on broiler growth and carcass yield. Poultry Sci. 81, 227-230.

Knovich, M. A., Il'yasova, D., Ivanova, A. and Molnár, I. (2007): The association between serum copper and anaemia in the adult Second National Health and Nutrition Examination Survey (NHANES II) population. British J. Nutr. 99, 1226-1229.

König, N., Baccini, P. and Ulrich, B. (1986): Der Einfluss der naturlichen organischen Substanzen auf die Metallverteilung zwischen Boden und Bodenlosung in einem sauren Waldboden. Z. Pflanz. Bodenkunde 149, 68-62.

Lee, H. H., Passarad, A. S., Brewer, G. J. and Owyang, G. J. (1989): Zinc absorption in human small intestine. Am. J. Physiol. 256, G87-G91.

Livens, F. R. (1991): Chemical reactions of metals with humic material. Environ. Pollut. 70, 183-208.

Mevlüt, K., Macit, M., Esenbuga, N., Durdag, H., Turgut, L. and Bilgin, Ö. C. (2004): Effect of supplemental humate at different levels on growth performance, slaughter and carcass traits of broilers. Int. J. Poultry Sci. 3, 406-410.

Owen, C. A. Jr. (1964): Absorption and excretion of Cu64-labelled copper by the rat. Am. J. Physiol. 207, 1203-1206.

Parks, C. W. (1998): The use of Menefee Humate ${ }^{\mathrm{TM}}$ in typical and low-crude protein diets for turkey toms and in the bioremediation of petroleum-contaminated soil amended with poultry litter as a co-substrate and nutrient source. Master's Thesis. North Carolina State University, Raleigh, NC, USA.

Peter, V. E., van den Berghe, P. V. and Klomp, L. W. (2009): New developments in the regulation of intestinal copper absorption. Nutr. Rev. 67, 658-672.

Rashida, M. A. (1974): Absorption of metals on sedimentary and peat humic acid purchase. Chem. Geol. 13, 115-123.

Reeves, P. G. (1997): Components of the AIN-93 diets as improvements in the AIN-76A rodent diet. J. Nutr. 127, 838S-841S.

Schuhmacher, A. and Gropp, J. M. (2000): Effect of humic acids on health state and performance of weaners. Proc. Soc. Nutr. Physiol. 9, 77.

Senesi, N., Bocian, D. F. and Sposito, G. (1985): Electron spin resonance investigation of copper (II) complexation by fulvic acid extracted from sewage sludge. Soil Sci. Soc. Am. J. 49, 119-126.

Stevenson, F. J. (1994): Humus Chemistry - Genesis, Composition, Reactions. John Wiley \& Sons, New York. 
Szabó, J., Vucskits, A. V., Berta, E., Andrásofszky, E., Bersényi, A. and Hullár, I. (2017): Effect of fulvic and humic acids on iron and manganese homeostasis in rats. Acta Vet. Hung. 65, $66-80$.

$\mathrm{Yu}, \mathrm{S}$. and Beynen, A. C. (1994): High tin reduces copper status in rats through inhibition of copper absorption. Br. J. Nutr. 73, 863-869.

Zraly, Z., Pisarikova, B., Trckova, M. and Navratilova, M. (2008): Effect of humic acids on lead accumulation in chicken organs and muscles. Acta Vet. Brno 77, 439-445. 